\title{
Amino acid digestibility in diets containing copra meal with $\beta$-mannanase fed to growing pigs
}

\author{
Jae Cheol Jang ${ }^{1}$, Dong Hyuk Kim ${ }^{1}$, Young Dal Jang ${ }^{1,2}$, and Yoo Yong Kim ${ }^{1, \star}$
}

* Corresponding Author: Yoo Yong Kim Tel: +82-2-880-4801, Fax: +82-2-878-5839,

E-mail: yooykim@snu.ac.kr

${ }^{1}$ Department of Agricultural Biotechnology, and Research Institute of Agriculture and Life Sciences, Seoul National University, Seoul 08826, Korea

2 Department of Animal and Food Science, University of Wisconsin-River Falls, River Falls, WI 54022, USA

ORCID

Jae Cheol Jang

https://orcid.org/0000-0001-9843-3186 Dong Hyuk Kim

https://orcid.org/0000-0001-6559-9999

Young Dal Jang

https://orcid.org/0000-0001-8403-1231

Yoo Yong Kim

https://orcid.org/0000-0001-8121-3291

Submitted Jan 10, 2021; Revised Feb 26, 2021 ; Accepted Mar 9, 2021
Objective: The objective of this study was to estimate standardized ileal digestibility (SID) of amino acids (AA) in growing pigs fed diets containing increasing levels of copra meal $(\mathrm{CM})$ with $\beta$-mannanase supplementation.

Methods: Twenty barrows (initial body weight: $34.43 \pm 0.11 \mathrm{~kg}$ ) surgically fitted with T-cannulas at the distal ileum were individually housed in metabolism crates. Pigs were allotted to 5 dietary treatments in a completely randomized design with 4 replicates per treatment. The dietary treatments were: i) NC, negative control, corn-soybean meal (SBM) based diet, ii) PC, positive control, basal diet $+0.10 \% \beta$-mannanase supplementation (800 $\mathrm{IU} / \mathrm{kg}$ ), iii) CM6, PC diet with 6\% CM supplementation, iv) CM12, PC diet with $12 \% \mathrm{CM}$ supplementation, and v) CM18, PC diet with $18 \% \mathrm{CM}$ supplementation. A nitrogen-free diet was used to estimate basal endogenous losses of AA for SID calculation. All experimental diets contained $0.5 \%$ chromic oxide as an indigestible marker. Each period consisted of a 4-d diet adaptation period and a 3-d ileal digesta collection period.

Results: There were no differences in apparent ileal digestibility (AID) and SID of all AA between the NC and PC treatments except that the PC treatment had lower AID and SID of glycine than the NC treatment $(\mathrm{p}<0.05)$. There were linear decreases in AID and SID of lysine $(\mathrm{p}<0.05)$ and aspartic acid $(\mathrm{p}=0.06$; tendency) with increasing levels of CM in the diets with $\beta$-mannanase.

Conclusion: The $\beta$-mannanase supplementation had no effect on AA digestibility in pigs fed the corn-SBM based diet but increasing levels of CM reduced SID of lysine and aspartic acid.

Keywords: Amino Acid Digestibility; $\beta$-Mannanase; Copra Meal; Standardized Ileal Digestibility; Pigs

\section{INTRODUCTION}

Copra meal (CM) is a by-product of oil-extraction from coconut kernel, and has been used in swine diets in the tropical regions. According to NRC [1], the CM contains 21.9\% crude protein (CP), $0.58 \%$ lysine (Lys), and $0.35 \%$ methionine (Met). However, heat damage in the CM processing (such as drying, oil extraction, and range of heat) may affect nutrient availability and result in fluctuation of standardized ileal digestibility (SID) of amino acids (AA) such as SID of Lys [2], varying from 21.4\% [3] to 72.8\% [4]. This may cause inaccurate assessment of digestible AA content in the diet formulation that could result in variations on growth performance and nutrient utilization in pigs [5-7].

The presence of high levels of non-starch polysaccharides (NSP) in the CM have restricted their use in monogastric animal diets, because of anti-nutritional properties of NSP [8]. The major NSP in the CM is $\beta$-mannan, which constitutes $25 \%$ to $35 \%$ [9]. It has been proposed that the $\beta$-mannan in the diets can be degraded into mannose or manno- 
oligosaccharides by supplementation of exogenous $\beta$-mannanase [10]. Although there have been a few dedicated studies evaluating SID of AA in the CM [3,4], limited information is available for estimating the SID of AA in the diets containing increasing levels of $\mathrm{CM}$ with $\beta$-mannanase fed to growing pigs. It is important to investigate how the inclusion level of CM in the diets affects AA digestibility because it was reported that the CM supplementation in the swine diets reduced protein digestibility [7]. Therefore, the objective of the current study was to determine the effect of increasing levels of $\mathrm{CM}$ in the diets with $\beta$-mannanase fed to growing pigs on SID of AA.

\section{MATERIALS AND METHODS}

\section{Animal care}

Animal Experimental Guidelines provided by the Seoul National University Institutional Animal Care and Use Committee (SNU- IACUC; SNU-160613-10) approved the experimental procedure.

\section{Experimental design, diets and feeding}

Twenty barrows ([Yorkshire $\times$ Landrace $] \times$ Duroc) with an initial body weight of $34.43 \pm 0.11 \mathrm{~kg}$ (stan-dard deviation =

Table 1. Analyzed chemical and amino acid composition of copra meal (as-fed basis)

\begin{tabular}{lc}
\hline Item & $\%$ \\
\hline Nutrient composition & \\
Dry matter & 90.27 \\
Crude protein & 22.18 \\
Ether extract & 3.84 \\
Calcium & 0.62 \\
Phosphorus & 0.35 \\
Amino acid composition & \\
Indispensable amino acids & \\
Arginine & 1.79 \\
Histidine & 0.32 \\
Isoleucine & 0.64 \\
Leucine & 1.23 \\
Lysine & 0.42 \\
Methionine & 0.21 \\
Phenylalanine & 0.68 \\
Threonine & 0.60 \\
Valine & 0.94 \\
Dispensable amino acids & \\
Alanine & 0.80 \\
Aspartic acid & 1.53 \\
Cysteine & 0.30 \\
Glutamic acid & 3.33 \\
Glycine & 0.90 \\
Proline & 0.64 \\
Serine & 0.73 \\
Tyrosine & 0.44 \\
\hline
\end{tabular}

2.7) were allocated to 5 dietary treatments in a completely randomized design with 4 replicates per treatment. The pigs were surgically fitted with a T- cannula at the distal ileum, approximately $15 \mathrm{~cm}$ cranial to the ileocecal junction [11]. After surgery, the pigs were housed in individual metabolic cages equipped with a feeder and a nipple drinker, and allowed to recover for 14- $\mathrm{d}$ before the beginning of the digesta collection.

The dietary treatments were: i) NC, negative control, a corn-soybean meal (SBM) based diet; ii) PC, positive control, basal diet $+0.10 \% \beta$-mannanase $(800 \mathrm{IU} / \mathrm{kg})$; iii) CM6, PC diet with 6\% CM supplementation; iv) CM12, PC diet with $12 \%$ CM supplementation; and v) CM18, PC diet with $18 \%$ CM supplementation (Table 2). The $\beta$-mannanase (800,000 U of $\beta$-mannanase/kg; Patent, 10-0,477,456-0000; CTC Bio Inc., Seoul, Korea) used in the present study was obtained from a commercial company (CTC Bio, Inc.), which has been produced by Bacillus subtilis (WL-7) grown on Luria broth. Each experimental diet was formulated to contain 3,265 kcal metabolizable energy (ME)/kg, 18.0\% CP, 0.95\% total Lys and $0.25 \%$ total Met and other nutrients were also met or exceeded NRC [12]. The CM was supplemented to each diet at the assigned level $(6 \%, 12 \%$, and $18 \%)$ by replacing corn and SBM, and the synthetic lysine was supplemented to meet the AA requirements. A corn starch-based $\mathrm{N}$-free diet was used to estimate basal endogenous losses of AA (Table 3). All experimental diets contained $0.5 \%$ chromic oxide as an indigestible marker.

\section{Sample collection}

During a 14-d recuperation period, all pigs were fed a common commercial growing phase diet containing 23\% CP and allowed ad libitum access to feed and water. The experimental period consisted of a 4-d adaptation period and a 3-d collection period. The quantity of feed provided daily per pig was calculated as approximately 2.0 times the estimated maintenance energy requirement (106 kcal of ME/kg $\mathrm{BW}^{0.75}$ ) adjusted in the NRC [12] on the basis of calculated ME concentration in the diets. The feed was divided into two equal meals and fed to pigs at 0700 and 1900 . Water was provided ad libitum. The ileal digesta were collected during $12 \mathrm{~h}$ from 0800 to 2100 for 3 consecutive days followed by Jorgensen et al [13]. A $200 \mathrm{~mL}$ of sterilized plastic bag was attached to T-cannula barrel using a cable tie. The bag was checked every $30 \mathrm{~min}$ and removed immediately when it exceeded a two-third level. The collected samples from each pig were placed in separate bags and stored at $-80^{\circ} \mathrm{C}$ to prevent bacterial degradation of $\mathrm{AA}$ in the ileal digesta. At the end of collection phase, all collected samples were thawed, pooled, lyophilized to obtain a solid form using a freeze-dryer, and then finely ground for chemical analysis. 
Table 2. Diet formulation and chemical composition of experimental diets

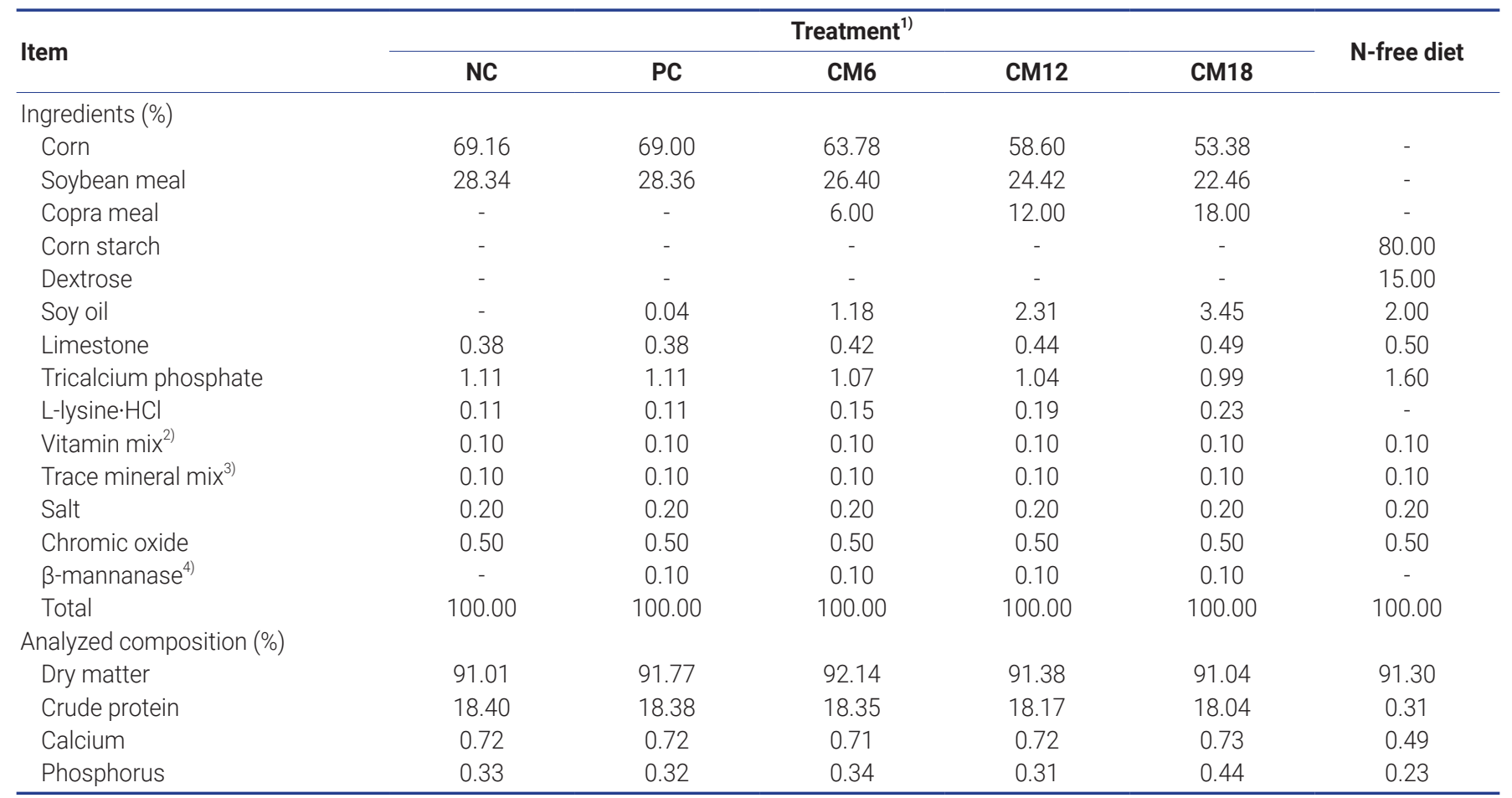

CM, copra meal.

1) $\mathrm{NC}$, negative control (corn-soybean meal-based diet); PC, positive control (basal diet $+0.10 \% \beta$-mannanase, $800 \mathrm{IU} / \mathrm{kg}$ diet); CM6, PC diet + 6\% CM; CM12, PC diet + 12\% CM; CM18, PC diet + 18\% CM.

2) Provided per kg of diet: vitamin $A, 16,000 \mathrm{IU}$; vitamin $\mathrm{D}_{3}, 3,200 \mathrm{IU}$; vitamin $\mathrm{E}, 35 \mathrm{IU}$; vitamin $\mathrm{K}_{3}, 5 \mathrm{mg}$; riboflavin, 6 mg; pantothenic acid, 16 mg; niacin, 32 mg; d-biotin, $128 \mu \mathrm{g}$, vitamin $\mathrm{B}_{12}, 20 \mu \mathrm{g}$.

3) Provided per kg of diet: Fe, 281 mg; Cu, 288 mg; Mn, 49 mg; l, 0.3 mg; Se, 0.3 mg.

4) CTCzyme: CTC Bio Inc. (Seoul, Korea).

Table 3. Analyzed amino acid composition of experimental diets (as-fed basis)

\begin{tabular}{|c|c|c|c|c|c|}
\hline \multirow{2}{*}{ Item } & \multicolumn{5}{|c|}{ Treatment $^{1)}$} \\
\hline & NC & PC & CM6 & CM12 & CM18 \\
\hline \multicolumn{6}{|c|}{ Indispensable amino acid (\%) } \\
\hline Histidine & 0.43 & 0.42 & 0.39 & 0.39 & 0.39 \\
\hline Isoleucine & 0.70 & 0.67 & 0.61 & 0.59 & 0.57 \\
\hline Leucine & 1.55 & 1.54 & 1.45 & 1.37 & 1.56 \\
\hline Phenylalanine & 0.86 & 0.84 & 0.78 & 0.76 & 0.78 \\
\hline Threonine & 0.75 & 0.72 & 0.67 & 0.67 & 0.68 \\
\hline Valine & 0.75 & 0.72 & 0.68 & 0.68 & 0.71 \\
\hline \multicolumn{6}{|c|}{ Dispensable amino acid (\%) } \\
\hline Alanine & 0.89 & 0.88 & 0.84 & 0.83 & 0.96 \\
\hline Proline & 0.66 & 0.68 & 0.61 & 0.58 & 0.68 \\
\hline Serine & 0.94 & 0.92 & 0.87 & 0.85 & 0.89 \\
\hline Tyrosine & 0.62 & 0.59 & 0.55 & 0.51 & 0.51 \\
\hline
\end{tabular}

CM, copra meal.

1) NC, negative control (corn-soybean meal-based diet); PC, positive control (basal diet + 0.10\% $\beta$-mannanase, $800 \mathrm{IU} / \mathrm{kg}$ diet); CM6, PC diet + 6\% CM;

CM12, PC diet + 12\% CM; CM18, PC diet + 18\% CM. 


\section{Chemical analysis}

Ingredient and diet samples were analyzed for dry matter (DM) by oven drying at $105^{\circ} \mathrm{C}$ for $3 \mathrm{~h}$ (method 935.29), CP (method 990.03), ether extract (EE; method 920.39), calcium (Ca; method 978.02), and phosphorus (P; method 946.06) according to AOAC [14]. Chromic oxide in ileal digesta and experimental diets was determined according to Fenton and Fenton [15]. The AA concentrations in the experimental diets and ileal digesta were analyzed using acid hydrolysis method (method 994.12) except for sulfur-containing AA (method 985.28) and tryptophan (method 988.15) followed by AOAC [14].

\section{Digestibility calculation}

The apparent ileal digestibility (AID) of AA was calculated with chromium contents in the diets and ileal digesta by the following equation developed by Fan et al [16];

$$
\mathrm{AID}=(100-[(\mathrm{AAd} / \mathrm{AAf}) \times(\mathrm{Crf} / \mathrm{Crd})]) \times 100(\%)
$$

where AAd is the amino acid content in ileal digesta DM, AAf is the amino acid content in feed DM, and Crf and Crd are the chromium content in feed and ileal digesta DM, respectively.

The endogenous AA losses (EAL, mg/kg DM intake), induced by the $\mathrm{N}$-free diet, were followed by the equation developed by Moughan et al [17];

$$
\mathrm{EAL}=[\mathrm{AAd} \times(\mathrm{Crf} / \mathrm{Crd})]
$$

The SID of AA was calculated based on the AID and EAL values according to the equation developed by Jondreville et al [18] as follows;

$$
\mathrm{SID}=\mathrm{AID}+(\mathrm{EAL} / \mathrm{AAf}) \times 100
$$

\section{Statistical analysis}

Data were analyzed by analysis of variance using the GLIMMIX procedure of SAS (SAS 9.4 Inst. Inc., Cary, NC, USA) with a completely randomized design. Individual pig was used as an experimental unit. Homogeneity of variances was confirmed and outliers were tested using the UNIVARIATE procedure of SAS (SAS 9.4 Inst. Inc., USA) and no outlier was removed. A single degree of freedom contrast was performed for the comparison between the NC and PC treatments to verify the $\beta$-mannanase effect. Orthogonal polynomial contrasts were used to evaluate linear and quadratic responses with increasing levels of $\mathrm{CM}$ in the diets using PC, CM6, $\mathrm{CM} 12$, and CM18 treatments. The least squares means of each treatment were calculated and the difference in means was tested using the PDIFF option with the Tukey's adjustment. Statistical differences were considered significant at $\mathrm{p}<0.05$ and tendency at $\mathrm{p}<0.10$.

\section{RESULTS AND DISCUSSION}

\section{Nutrient composition of the ingredients and diets}

The chemical (DM, CP, EE, Ca, and P) and AA composition of ingredients and experimental diets are provided in Tables 1 and 2, respectively. The content of CP in the CM used in this experiment had a similar value compared with previous studies $[1,19,20]$. The EE content in the CM was comparable with Lee and Kim [21]. The AA composition of CM was comparable with the composition reported by Sulabo et al [4].

\section{Amino acid digestibility}

There were no differences in the AID and SID of all AA between the NC and PC treatments except that the PC treatment had lower AID and SID of glycine (Gly) than the NC treatment ( $<<0.05$; Table 4 , and 5, respectively). The AID of Lys and aspartic acid (Asp) showed linear decreases $(\mathrm{p}<0.05)$ with increasing inclusion levels $\mathrm{CM}$ in the diets containing $\beta$-mannanase. There were linear decreases in SID of Lys ( $\mathrm{p}<$ 0.05 ) and of Asp ( $\mathrm{p}=0.06$; tendency) with increasing inclusion rate of $\mathrm{CM}$ in the diets containing $\beta$-mannanase.

The AID and SID values for AA in the NC treatment agreed with published values $[4,22]$. No differences in the SID of AA (except for Gly) between the NC and PC treatments indicated that the $\beta$-mannanase supplementation did not affect AA digestibility of the corn-SBM based diets. This result could be explained by the fact that $\beta$-mannanase only degrades $\beta$-mannans as substrates but not protein in the diets. This result agrees with previous studies that reported that the $\beta$-mannanase supplementation in corn-SBM based diets for nursery and growing pigs did not affect protein digestibility $[7,23]$. However, reasons for the reduction in SID of Gly by $\beta$-mannanase supplementation is still unclear.

In the current study, reduced SID of Lys and Asp were observed with increasing inclusion rate of $\mathrm{CM}$ in the diets containing $\beta$-mannanase. In addition, there were numerical decreases in the SID of other AA with increasing level of $\mathrm{CM}$ in the diets containing $\beta$-mannanase. To our knowledge, no data for SID of AA in the diets containing CM with $\beta$-mannanase have been published. Sulabo et al [4] reported that the AID and SID of AA in CM where the range is from $67.6 \%$ to $83.5 \%$ for AID of AA and from $72.8 \%$ to $128.8 \%$ for SID of AA, which were significantly lower than corn [24] and SBM [4]. This implies that the addition of $\mathrm{CM}$ in corn-SBM based diets could reduce AA digestibility. The $\mathrm{CM}$ processing involves several drying steps ranging from $104^{\circ} \mathrm{C}$ to $110^{\circ} \mathrm{C}$ for up to $30 \mathrm{~min}$ to reduce moisture content to $2 \%$ to $3 \%$ [4]. Therefore, the heat damage during the CM processing may occur and accelerate Maillard reactions, in turn resulting in reduced AA digestibility [20]. 
Table 4. Effect of increasing levels of copra meal with $\beta$-mannanase on apparent ileal digestibility of amino acids in pigs ${ }^{1)}$

\begin{tabular}{|c|c|c|c|c|c|c|c|c|c|}
\hline \multirow{2}{*}{ Item } & \multicolumn{5}{|c|}{ Treatment $^{2)}$} & \multirow{2}{*}{ SEM } & \multicolumn{3}{|c|}{ p-values ${ }^{3)}$} \\
\hline & NC & PC & CM6 & CM12 & CM18 & & NC vs PC & Lin & Quad \\
\hline \multicolumn{10}{|c|}{ Indispensable amino acid (\%) } \\
\hline Histidine & 91.14 & 90.19 & 90.40 & 89.88 & 87.53 & 1.353 & 0.50 & 0.23 & 0.41 \\
\hline Isoleucine & 89.16 & 87.84 & 88.21 & 87.99 & 84.72 & 1.284 & 0.42 & 0.13 & 0.20 \\
\hline Leucine & 89.86 & 89.15 & 90.37 & 90.11 & 90.60 & 0.655 & 0.59 & 0.11 & 0.50 \\
\hline Phenylalanine & 90.05 & 89.39 & 89.70 & 89.92 & 89.32 & 0.533 & 0.59 & 0.99 & 0.47 \\
\hline Threonine & 84.30 & 81.38 & 82.77 & 82.16 & 80.44 & 1.039 & 0.25 & 0.53 & 0.22 \\
\hline Valine & 85.44 & 82.39 & 83.86 & 83.26 & 82.17 & 1.224 & 0.26 & 0.84 & 0.36 \\
\hline \multicolumn{10}{|c|}{ Dispensable amino acid (\%) } \\
\hline Alanine & 83.35 & 81.22 & 82.93 & 81.79 & 83.56 & 1.210 & 0.37 & 0.28 & 0.98 \\
\hline Proline & 85.02 & 84.35 & 81.23 & 84.41 & 83.19 & 1.970 & 0.86 & 0.97 & 0.65 \\
\hline Serine & 87.25 & 86.10 & 86.84 & 85.87 & 84.60 & 0.974 & 0.47 & 0.26 & 0.35 \\
\hline Tyrosine & 89.21 & 88.46 & 88.79 & 87.88 & 85.68 & 1.150 & 0.65 & 0.12 & 0.32 \\
\hline
\end{tabular}

CM, copra meal; SEM, standard error of the means.

1) $\mathrm{n}=4$ per treatment.

${ }^{2)} \mathrm{NC}$, negative control (corn-soybean meal-based diet); PC, positive control (basal diet $+0.10 \% \beta$-mannanase, $800 \mathrm{IU} / \mathrm{kg}$ diet); CM6, PC diet + 6\% CM; CM12, PC diet + 12\% CM; CM18, PC diet + 18\% CM

${ }^{3)} \mathrm{p}$-values are for the single degree of freedom contrast between NC and PC treatments and linear and quadratic responses based on CM supplementation levels with PC, CM6, CM12, and CM18 treatments.

Table 5. Effect of increasing levels of copra meal with $\beta$-mannanase on standardized ileal digestibility of amino acids in pigs ${ }^{1)}$

\begin{tabular}{|c|c|c|c|c|c|c|c|c|c|}
\hline \multirow{2}{*}{ Item } & \multicolumn{5}{|c|}{ Treatment $^{2)}$} & \multirow{2}{*}{ SEM } & \multicolumn{3}{|c|}{ p-values ${ }^{3)}$} \\
\hline & NC & PC & CM6 & CM12 & CM18 & & NC vs PC & Lin & Quad \\
\hline \multicolumn{10}{|c|}{ Indispensable amino acid (\%) } \\
\hline Histidine & 96.02 & 95.19 & 95.78 & 95.27 & 92.92 & 1.344 & 0.55 & 0.29 & 0.34 \\
\hline Isoleucine & 95.58 & 94.56 & 95.59 & 95.62 & 92.61 & 1.195 & 0.52 & 0.35 & 0.16 \\
\hline Leucine & 93.66 & 92.98 & 94.44 & 94.42 & 94.38 & 0.606 & 0.61 & 0.15 & 0.18 \\
\hline Phenylalanine & 93.88 & 93.32 & 93.93 & 94.27 & 93.55 & 0.613 & 0.64 & 0.71 & 0.30 \\
\hline Threonine & 91.90 & 89.30 & 91.28 & 90.66 & 88.88 & 0.988 & 0.30 & 0.73 & 0.14 \\
\hline Valine & 93.70 & 91.00 & 92.97 & 92.38 & 90.97 & 1.224 & 0.31 & 0.91 & 0.23 \\
\hline \multicolumn{10}{|c|}{ Dispensable amino acid (\%) } \\
\hline Alanine & 90.99 & 88.95 & 91.03 & 89.98 & 90.64 & 0.990 & 0.39 & 0.45 & 0.56 \\
\hline Proline & 111.83 & 110.38 & 110.25 & 114.92 & 109.41 & 1.942 & 0.70 & 0.85 & 0.21 \\
\hline Serine & 94.16 & 93.16 & 94.31 & 93.51 & 91.94 & 0.928 & 0.53 & 0.35 & 0.21 \\
\hline Tyrosine & 94.70 & 94.22 & 94.97 & 94.55 & 92.35 & 0.990 & 0.77 & 0.29 & 0.25 \\
\hline
\end{tabular}

CM, copra meal; SEM, standard error of the means.

1) $\mathrm{n}=4$ per treatment.

2) NC, negative control (corn-soybean meal-based diet); PC, positive control (basal diet + 0.10\% $\beta$-mannanase, $800 \mathrm{IU} / \mathrm{kg}$ diet); CM6, PC diet + 6\% CM; CM12, PC diet + 12\% CM; CM18, PC diet + 18\% CM.

${ }^{3)} \mathrm{p}$-values are for the single degree of freedom contrast between NC and PC treatments and linear and quadratic responses based on CM supplementation levels with $\mathrm{PC}, \mathrm{CM} 6, \mathrm{CM} 12$, and $\mathrm{CM} 18$ treatments. 
This result agrees with Jang et al [7] who reported that the protein digestibility decreased with increasing inclusion rate of $\mathrm{CM}$ in the diets containing $\beta$-mannanase for growing pigs.

In conclusion, the results of the current study indicated that the $\beta$-mannanase supplementation did affect AA digestibility in pigs and that increasing the inclusion level of $\mathrm{CM}$ could reduce SID of AA, particularly Lys and Asp.

\section{CONFLICT OF INTEREST}

We certify that there is no conflict of interest with any financial organization regarding the material discussed in the manuscript.

\section{ACKNOWLEDGMENTS}

The present manuscript is based on research supported by Rural Development Administration (Republic of Korea; 50020180039).

\section{REFERENCES}

1. Committee on Nutrient Requirements of Swine, National Research Council. Nutrient requirements of swine. 11th ed. Washington, DC, USA: National Academy Press; 2012.

2. Stein HH, Casas GA, Abelilla JJ, Liu Y, Sulabo RC. Nutritional value of high fiber co-products from the copra, palm kernel, and rice industries in diets fed to pigs. J Anim Sci Biotechnol 2015;6:56. https://doi.org/10.1186/s40104-0150056-6

3. Son AR, Park CS, Park KR, Kim BG. Amino acid digestibility in plant protein sources fed to growing pigs. Asian-Australas J Anim Sci 2019;32:1745-52. https://doi.org/10.5713/ajas. 19.0037

4. Sulabo RC, Ju WS, Stein HH. Amino acid digestibility and concentration of digestible and metabolizable energy in copra meal, palm kernel expellers, and palm kernel meal fed to growing pigs. J Anim Sci 2013;91:1391-9. https://doi. org/10.2527/jas.2012-5281

5. Kim BG, Lee JH, Jung HJ, Han YK, Park KM, Han IK. Effect of partial replacement of soybean meal with palm kernel meal and copra meal on growth performance, nutrient digestibility and carcass characteristics of finishing pigs. Asian-Australas J Anim Sci 2001;14:821-30. https://doi. org/10.5713/ajas.2001.821

6. Kim HJ, Nam SO, Jeong JH, et al. Various levels of copra meal supplementation with $\beta$-Mannanase on growth performance, blood profile, nutrient digestibility, pork quality and economical analysis in growing-finishing pigs. J Anim Sci Technol 2017;59:19. https://doi.org/10.1186/s40781-0170144-6
7. Jang JC, Kim DH, Hong JS, Jang YD, Kim YY. Effects of copra meal inclusion level in growing-finishing pig diets containing $\beta$-mannanase on growth performance, apparent total tract digestibility, blood urea nitrogen concentrations and pork quality. Animals 2020;10:1840. https:/doi.org/10. 3390/ani10101840

8. Odetallah HN, Ferket PR, Grimes JL, McNaughton JL. Effect of mannan-endo-1, 4- $\beta$-mannosidase on the growth performance of turkeys fed diets containing 44 and $48 \%$ crude protein soybean meal. Poult Sci 2002;81:1322-31. https://doi.org/10.1093/ps/81.9.1322

9. Saittagaroon S, Kawakishi S, Namiki M. Characterisation of polysaccharides of copra meal. J Sci Food Agric 1983;34:85560. https://doi.org/10.1002/jsfa.2740340813

10. McCleary BV. Synthesis of $\beta$-D-mannosidase and exo- $\beta$-Dmannanase. Method Enzymol 1988;160:515-8. https://doi. org/10.1016/0076-6879(88)60161-3

11. Stein HH, Shipley CF, Easter RA. Technical note: A technique for inserting a T-cannula into the distal ileum of pregnant sows. J Anim Sci 1998;76:1433-6. https://doi.org/10.2527/ 1998.7651433x

12. Committee on Nutrient Requirements of Swine, National Research Council. Nutrient requirements of swine. 10th ed. Washington, DC, USA: National Academy Press; 1998.

13. Jorgensen H, Sauer WC, Thacker PA. Amino acid availabilities in soybean meal, sunflower meal, fish meal and meat and bone meal fed to growing pigs. J Anim Sci 1984; 58:926-34. https://doi.org/10.2527/jas1984.584926x

14. Official methods of analysis of AOAC International. 18th ed. Gaithersburg, MD, USA: AOAC International; 2005.

15. Fenton TW, Fenton M. An improved procedure for the determination of chromic oxide in feed and feces. Can J Anim Sci 1979;59:631-4. https://doi.org/10.4141/cjas79-081

16. Fan MZ, Sauer WC. Determination of apparent ileal amino acid digestibility in barley and canola meal for pigs with the direct, difference, and regression methods. J Anim Sci 1995; 73:2364-74. https://doi.org/10.2527/1995.7382364x

17. Moughan PJ, Schuttert G, Leenaars M. Endogenous amino acid flow in the stomach and small intestine of the young growing pig. J Sci Food Agric 1992;60:437-42. https://doi. org/10.1002/jsfa.2740600406

18. Jondreville C, Van den Broecke J, Gatel F, Van Cauwenberghe S. Ileal digestibility of amino acids in feedstuffs for pigs. Paris, France: Eurolysine/ITFC publication; 1995.53 p.

19. Jang YD, Kim YY. Short Communication: Energy values and apparent total tract digestibility coefficients of copra meal and palm kernel meal fed to growing pigs. Can J Anim Sci 2013;93:517-21. https://doi.org/10.4141/cjas2013-025

20.Son AR, Hyun Y, Htoo JK, Kim BG. Amino acid digestibility in copra expellers and palm kernel expellers by growing pigs. Anim Feed Sci Technol 2014;187:91-7. https://doi.org/10. 1016/j.anifeedsci.2013.09.015 


\section{$113^{\prime}$}

21.Lee SA, Kim BG. Classification of copra meal and copra expellers based on ether extract concentration and prediction of energy concentrations in copra byproducts. J Anim Plant Sci 2017;27:34-9.

22. Adebiyi AO, Ragland D, Adeola O, Olukosi OA. Apparent or standardized ileal digestibility of amino acids of diets containing different protein feedstuffs fed at two crude protein levels for growing pigs. Asian-Australas J Anim Sci 2015;28:132734. https://doi.org/10.5713/ajas.14.0914

23.Jang JC, Kim KH, Kim DH, et al. Effects of increasing levels of palm kernel meal containing $\beta$-mannanase to growingfinishing pig diets on growth performance, nutrient digestibility, and pork quality. Livest Sci 2020;238:104041. https:// doi.org/10.1016/j.livsci.2020.104041

24. Jeon SM, Hosseindoust A, Choi YH, et al. Comparative standardized ileal amino acid digestibility and metabolizable energy contents of main feed ingredients for growing pigs when adding dietary $\beta$-mannanase. Anim Nutr 2019;5:35965. https://doi.org/10.1016/j.aninu.2019.07.001 